\title{
PENGARUH SIKAP DAN PENDIDIKAN KEWIRAUSAHAAN PADA MINAT BERWIRAUSAHA
}

\author{
Hendra Prasetya ${ }^{1)}$, dan Ricky Angga Ariska ${ }^{2)}$ \\ Fakultas Ekonomi dan Bisnis ${ }^{1)}$, Universitas Wijaya Kusuma Surabaya ${ }^{2)}$ \\ Jl.Dukuh Kupang XXV/54 Surabaya 60225 \\ E-mail: hendraprasetya@uwks.ac.id1),rickyanggaariska@uwks.ac.id2)
}

\begin{abstract}
ABSTRAKS
Permasalahan pada penelitian ini adalah apakah sikap dan pendidikan kewirausahaan secara parsial berpengaruh signifikan terhadap minat berwirausaha pada mahasiswa Program Studi Manajemen Fakultas Ekonomi Dan Bisnis Universitas Wijaya Kusuma Surabaya. Tujuannya untuk mengetahui pengaruh sikap dan pendidikan kewirausahaan secara parsial terhadap minat berwirausaha apakah signifikan ataukah tidak. Variabel bebas berupa sikap dan pendidikan kewirausahaan sedangkan variabel terikat berupa minat berwirausaha. Penentuan sampel dengan purposive sampling dan analisisnya dengan regresi linier berganda. Hasil pengujian hipotesis dengan uji t adalah sikap berpengaruh positif dan signifikan terhadap minat berwirausaha pada mahasiswa Program Studi Manajemen Fakultas Ekonomi dan Bisnis Universitas Wijaya Kusuma Surabaya sedangkan pendidikan kewirausahaan pengaruhnya positif dan tidak signifikan pada minat berwirausaha. Penanaman sikap kewirausahaan perlu semakin ditumbuhkan antara lain melalui sikap percaya diri, inisiatif, jiwa kepemimpinan, keberanian dalam mengambil risiko dan kreatif. Pihak fakultas Ekonomi dan Bisnis Universitas Wijaya Kusuma Surabaya dan dosen pengampu mata kuliah Kewirausahaan harus berusaha semaksimal mungkin untuk menjadikan mata kuliah tersebut sebagai pemicu munculnya minat berwirausaha di kalangan mahasiswa, antara lain melakukan penataan kembali materi kuliah, proses pembelajaran, sarana dan prasarana perkuliahan serta kegiatan praktik berwirausaha.
\end{abstract}

Kata kunci: Minat berwirausaha, Pendidikan kewirausahaan,Sikap.

\section{ABSTRACT}

The problem in this study is whether entrepreneurial attitudes and education partially have a significant on entrepreneurial interest student of management study program, Faculty of Economics and Business, Wijaya Kusuma University, Surabaya. The aim is to determine the effect entrepreneurial attitudes and education on interest in entrepreneurship whether significant or not. The independent variables are entrepreneurial attitudes and education, while the dependent variable is interest in entrepreneurship. The sample is determined by purposive sampling while the analysis is using multiple linear regression. The results of hypothesis testing carried out by $t$ test are attitudes have a positive and significant effect on entrepreneurial interest in students of management study program of Faculty of Economics and Business, University of Wijaya Kusuma Surabaya while entrepreneurship education has a positive effect but does not have a significant on entrepreneurship in interest. To increase the interest in entrepreneurship among students, the cultivation of entrepreneurial attitudes needs to be fostered, among others, through the culvitation of selfconfidence, inisiative, a spirit of leadership, courage in taking risks and being creative. The Faculty of Economics and Business, University of Wijaya Kusuma Surabaya and lecturers of the Entrepreneurship Course must do their best to make this course a trigger for the emergence entrepreneurial interes among students. Things that can be done include rearranging course materials, the learning process, lecture facilities and infrastructure as well as entrepreneurial practice activities.

Keyword: attitude, entrepreneurship education, entrepreneurial interest. 


\section{PENDAHULUAN}

Kegiatan kewirausahaan dapat memberikan manfaat finansial berupa keuntungan bagi wirausaha dan manfaat sosial bagi masyarakat dan negara. Masyarakat dapat memperoleh kesempatan bekerja dan penghasilan sehingga dapat mengurangi jumlah pengangguran di suatu negara. Negara juga dapat memperoleh manfaat dalam bentuk pendapatan dari pajak dan devisa.

Menurut Vanpraag dan Versloot seperti dikutip oleh Ardiyani dan Kusuma (2016) menyatakan bahwa pertumbuhan ekonomi dapat dirangsang melalui kegiatan kewirausahaan, sedangkan Sharma dan Madan (2014) menyatakan bahwa kegiatan kewirausahaan dapat membantu dalam mengurangi pengangguran. Jika kegiatan kewirausahaan di suatu negara dapat berkembang dengan baik maka dapat membantu negara tersebut dalam mengatasi masalah kemiskinan, pengangguran, kesenjangan pendapatan masyarakat dan pertumbuhan ekonomi. Azwar (2013) menyatakan bahwa salah satu alternatif untuk mengurangi pengangguran adalah dengan menumbuhkan jiwa kewirausahaan pada mahasiswa. Mahasiswa yang telah memperoleh pendidikan kewirausahaan diharapkan jiwa kewirausahaannya akan semakin tumbuh sehingga akan mendorongnya untuk membuka suatu usaha sebagai seorang wirausahawan. mahasiswa yang berwirausaha dapat menciptakan pekerjaan sehingga dapat mengurangi jumlah pengangguran.

Jumlah pengangguran di Indonesia pada tahun 2016 - 2019 mengalami penurunan seperti tampak pada tabel berikut ini:

Tabel 1. Pengangguran Di Indonesia

\begin{tabular}{|l|l|}
\hline Tahun & Jumlah Pengangguran(juta orang) \\
\hline 2016 & 7,02 \\
\hline 2017 & 7,01 \\
\hline 2018 & 6,87 \\
\hline 2019 & 6,82 \\
\hline
\end{tabular}

Sumber: https://databoks.katadata.co.id (diakses 23-05-2021)

Penanaman nilai perilaku yang kreatif dan inovatif dalam menciptakan dan menanggapi peluang usaha, pengetahuan dan ketrampilan dalam berwirausaha dapat diberikan melalui pendidikan kewirausahaan karena penanaman nilai perilaku tersebut dapat mendorong munculnya minat berwirausaha yang merupakan titik awal bagaimana menjalankan suatu usaha dan menghadapi risiko. Perguruan Tinggi merupakan salah satu tempat untuk membentuk karakter kewirausahaan bagi para mahasiswa. Nursito dan Nugroho (2013), menyatakan bahwa pendidikan kewirausahaan mempunyai peran dalam membentuk pola pikir, sikap dan perilaku dalam berwirausaha melalui kegiatan kewirausahaan. Upaya yang dapat dilakukan oleh Perguruan Tinggi dalam membentuk karakter kewirausahaan bagi para mahasiswa adalah membekali mereka dengan pendidikan kewirausahaan dalam bentuk memasukkan mata kuliah Kewirausahaan dalam kurikulum akademik sebagai mata kuliah wajib. Chimechuka (2013) mengemukakan bahwa penyelenggaraan pendidikan kewirausahaan di perguruan tinggi mempunyai peran penting dalam rangka mendorong pertumbuhan kewirausahaan di suatu Negara. Sharma dan Madan (2014) mengemukakan bahwa kegiatan kewirausahaan akan memberikan pemahaman bagi generasi muda mengenai terdapatnya banyak pilihan untuk menentukan masa depannya dengan memulai membuka suatu usaha sendiri dan tidak menggantungkan pekerjaan dari orang lain.

Yang (2013) menyatakan bahwa seseorang yang memiliki sikap positif terhadap kegiatan kewirausahaan maka kemungkinannya akan lebih tertarik untuk menjadi seorang wirausahawan dalam rangka mencapai aktualisasi diri. Di dalam Teori Planned Behavior (TPB) bahwa sikap dapat membentuk niat seseorang dan mempengaruhi perilaku. Kewirausahaan merupakan perwujudan jiwa seseorang melalui sikap dan perilaku dalam melakukan usaha secara kreatif dan inovatif.

Mahasiswa perlu mendapatkan dorongan agar berminat untuk melakukan kegiatan kewirausahaan. Untuk itu mahasiswa perlu diberikan pemahaman mengenai sikap seorang wirausahawan, 
mengidentifikasi permasalahan untuk diubah menjadi peluang bisnis dan mewujudkannya menjadi suatu usaha yang nyata. Mahasiswa dapat memulai usaha dengan modal seadanya yang dimiliki walaupun jumlahnya kecil dan jangan takut menghadapi kegagalan serta berani menghadapi risiko.

Pendidikan kewirausahaan sudah dimasukkan dalam kurikulum Fakultas Ekonomi Dan Bisnis Universitas Wijaya Kusuma Surabaya. Pendidikan kewirausahaan tersebut diwujudkan dalam mata kuliah Kewirausahaan. Mata kuliah Kewirausahaan merupakan mata kuliah yang wajib ditempuh oleh mahasiswa jenjang S1 di semua program studi yang ada di Fakultas Ekonomi Dan Bisnis Universitas Wijaya Kusuma Surabaya.

Dari uraian yang telah dikemukakan di atas maka dapat dimunculkan dua rumusan permasalahan yang akan diteliti dalam penelitian ini. Pertama, apakah sikap berpengaruh positif dan signifikan terhadap minat berwirausaha pada mahasiswa program studi Manajemen di Fakultas Ekonomi dan Bisnis Universitas Wijaya Kusuma Surabaya?. Ke dua, apakah pendidikan kewirausahaan berpengaruh positif dan signifikan terhadap minat berwirausaha pada mahasiswa program studi Manajemen di Fakultas Ekonomi dan Bisnis Universitas Wijaya Kusuma Surabaya?. Tujuan yang ingin dicapai yang didasarkan pada rumusan permasalahan yang diteliti yaitu untuk mengetahui apakah sikap dan pendidikan kewirausahaan secara parsial berpengaruh positif dan signifikan terhadap minat berwirausaha pada mahasiswa program studi Manajemen di Fakultas Ekonomi dan Bisnis Universitas Wijaya Kusuma Surabaya. Hasil dari penelitian ini dapat dimanfaatkan oleh Fakultas Ekonomi dan Bisnis Universitas Wijaya Kusuma Surabaya sebagai masukan bahan pertimbangan dalam membuat kebijakan yang berkaitan dengan mata kuliah Kewirausahaan. Bagi peneliti selanjutnya dapat memanfaatkan hasil penelitian ini sebagai bahan pertimbangan ketika akan melakukan penelitian yang topiknya ada kaitannya dengan topic penelitian ini.

\section{LANDASAN TEORI DAN PENGEMBANGAN HIPOTESIS}

\subsection{Kewirausahaan}

Menurut Hisrich et al. seperti dikutip oleh Ardiyani dan Kusuma (2016) menyatakan bahwa kewirausahaan merupakan kegiatan dalam penciptaan sesuatu yang baru yang bernilai dengan mempertimbangkan berbagai risiko untuk mencapai tujuan tertentu. Kewirausahaan menurut Kao seperti dikutip oleh Echdar (2013: 2) merupakan upaya penciptaan nilai dengan cara melakukan pengenalan peluang usaha, risiko, ketrampilan berkomunikasi dan sumber daya untuk menghasilkan produk. Di dalam kegiatan kewirausahaan terjadi proses penciptaan sesuatu yang baru dan bernilai dalam bentuk produk dengan menggunakan sumber daya yang dimiliki dan mempertimbangkan risiko yang mungkin akan dihadapi guna mencapai tujuan . Kegiatan kewirausahaan tidak lepas dengan risiko yang akan dihadapi maka seorang wirausahawan harus memiliki keberanian dalam mengambil risiko.

Seorang wirausahawan harus mampu mengambil atau menemukan peluang, menganalisis peluang dan mengambil keputusan untuk mencapai tujuan. Kegiatan kewirausahaan dimulai dengan mengenali peluang usaha. Peluang usaha yang sudah dipilih kemudian diwujudkan dalam bentuk produkyang bernilai. Produk yang dihasilkan diupayakan memiliki ciri khas yang berbeda dengan produk yang sudah ada artinya setiap saat dilakukan inovasi. Penggunaan sumber daya untuk menghasilkan produk harus dilakukan secara optimal.

\subsection{Minat Berwirausaha}

Menurut Slameto seperti dikutip oleh Winarsih (2014) mengemukakan bahwa minat merupakan kondisi perasaan seseorang yang tertarik dan lebih menyukai suatu obyek tanpa paksaan pihak lain. Minat berkaitan dengan keinginan dan ketertarikan seseorang akan suatu obyek sehingga antara satu orang dengan orang lain minatnya belum tentu sama. Seseorang yang berminat akan sesuatu berarti orang tersebut menyenangi dan tertarik sehingga kecenderungannya akan menggunakan sesuatu obyek atau melakukan suatu kegiatan. Pengalaman yang berkesan yang pernah dialami seseorang dapat membentuk minat, misalnya pernah mengikuti pelatihan kewirausahaan, mempraktikkan suatu 
kegiatan. Jadi minat berkaitan dengan perasaan senang, ketertarikan, keinginan, kemauan dan harapan.

Katz dan Gatner dalam Budiati et al. (2012), menyatakan bahwa minat berwirausaha sebagai proses mencari informasi yang akan digunakan untuk membuka suatu usaha. Minat berwirausaha menurut Li seperti dikutip oleh Budiati et al. (2012) merupakan keinginan diri sendiri untuk membuka usaha secara manndiri. Informasi yang diperlukan mengenai peluang usaha, hambatan, sumber daya yang dibutuhkan dan risiko yang mungkin akan dihadapi. Seseorang yang mempunyai minat berwirausaha berarti memiliki kemauan, perasaan tertarik dan senang untuk menjalankan suatu usaha.

\subsection{Sikap}

Sikap menunjukkan kecenderungan respon yang diberikan oleh seseorang secara konsisten atas suatu obyek, baik dalam perasaan senang atau tidak senang. Sikap seseorang dapat dilihat dari bagaimana reaksinya terhadap suatu obyek . Pengertian sikap menurut Suprapti dalam Ardiyani dan Kusuma (2016) adalah cerminan perasaan seseorang yang diwujudkan dalam bentuk kesenangan atau ketidaksenangan pada suatu obyek. Sikap menunjukkan respon seseorang atas suatu obyek dimana respon tersebut bisa berupa perasaan menyukai atau tidak menyukai. Ketika situasinya berbeda maka sikap seseorang bisa berbeda. Begitu juga sikap seseorang dengan orang lain dalam memandang suatu obyek yang sama belum tentu sama. Sifat dari sikap menurut Suprapti dalam Ardiyani dan Kusuma (2016) meliputi: bisa dipelajari, memiliki lkonsistensi dan bisa berbeda jika situasinya berbeda. Menurut Walgito seperti dikutip oleh Winarsih (2014) menyebutkan bahwa sikap merupakan pendapat dan keyakinan seseorang atas suatu obyek yang diikuti dengan perasaan tertentu yang menjadi motivasi bagi dirinya dalam berperilaku.

\subsection{Pendidikan Kewirausahaan}

Chimechuka (2013) menyatakan bahwa perguruan tinggi berperan dalam mendorong pertumbuhan kewirausahaan di suatu Negara melalui penyelenggaraan pendidikan kewirausahaan. Pendidikan kewirausahaan menurut Alberti dan Poli dalam Ardiyani dan Kusuma (2016) adalah kegiatan mentransfer kompetensi kewirausahaan yang berupa konsep, ketrampilan dan kesadaran mental yang dilakukan secara formal dan terstruktur. Pendidikan kewirausahaan dapat dilakukan secara formal melalui lembaga pendidikan dapat dijadikan sebagai upaya dalam menciptakan wirausahawan. Penciptaan wirausahawan dapat juga dilakukan melalui pendidikan non formal melalui pelatihan kewirausahaan kepada masyarakat. Penciptaan wirausahawan akan lebih cepat jika sudah dimulai dari lingkungan keluarga.

Nursito dan Nugroho (2013) mengemukakan bahwa peran pendidikan dalam kegiatan kewirausahaan adalah dalam hal pembentukan pola pikir, sikap dan perilaku menjadi wirausaha. Pendidikan kewirausahaan berperan dalam memotivasi seseorang untuk menjadi wirausaha karena seseorang yang mengikuti pendidikan kewirausahaan bisa belajar tentang dasar-dasar berwirausaha yang dapat dijadikan bekal untuk memulai suatu usaha. Pendidikan kewirausahaan dapat digunakan untuk meningkatkan pengetahuan dan kemampuan berwirausaha, praktik berwirausaha dan memajukan kegiatan wirausaha yang telah dijalankan.

Dengan mengikuti pendidikan kewirausahaan maka seseorang akan semakin memahami keuntungan dan tertarik menjadi wirausaha. Menurut Silvia dalam ardiyani dan Kusuma (2016), menyatakan bahwa mahasiswa yang pernah memperoleh pendidikan kewirausahaan memiliki intensi berwirausaha yang lebih tinggi dibandingkan dengan mahasiswa yang belum pernah memperoleh pendidikan kewirausahaan.

\subsection{Penelitian Terdahulu}

Penelitian terdahulu yang ada kaitannya dengan penelitian saat ini disajikan dalam tabel berikut ini:

Tabel 2. Ringkasan Penelitian Terdahulu 


\begin{tabular}{|c|c|c|c|}
\hline No & Judul & Teknik Analisis & Hasil \\
\hline 1. & 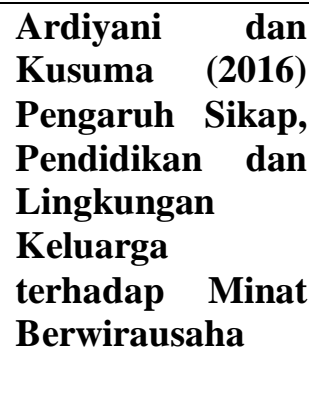 & $\begin{array}{ll}\text { Regresi } & \text { linier } \\
\text { berganda } & \end{array}$ & $\begin{array}{l}\text { Sikap, } \\
\text { pendidikan dan } \\
\text { lingkungan } \\
\text { keluarga } \\
\text { berpengaruh } \\
\text { positif dan } \\
\text { signifikan minat } \\
\text { terhdap map } \\
\text { berwirausaha }\end{array}$ \\
\hline 2. & $\begin{array}{l}\text { Winarsih (2014), } \\
\text { Minat } \\
\text { BerWirausaha } \\
\text { Ditinjau Dari } \\
\text { Motivasi Dan } \\
\text { Sikap } \\
\text { Kewirausahaan }\end{array}$ & $\begin{array}{l}\text { Regresi linier } \\
\text { berganda }\end{array}$ & $\begin{array}{l}\text { Motivasi dan } \\
\text { sikap } \\
\text { kewirausahaan } \\
\text { brpengaruh } \\
\text { positif dan } \\
\text { signifikan } \\
\text { terhadap minat } \\
\text { berwirausaha }\end{array}$ \\
\hline 3. & $\begin{array}{l}\text { Adhitama (2014), } \\
\text { Faktor Faktor } \\
\text { Yang } \\
\text { Mempengaruhi } \\
\text { Minat } \\
\text { Berwirausaha }\end{array}$ & $\begin{array}{l}\text { Regresi linier } \\
\text { berganda }\end{array}$ & $\begin{array}{l}\text { Ekspetasi } \\
\text { pendapatan, } \\
\text { lingkungan } \\
\text { keluarga dan } \\
\text { pendidikan } \\
\text { berpengaruh } \\
\text { positif terhadap } \\
\text { minat } \\
\text { berwirausaha }\end{array}$ \\
\hline
\end{tabular}

Sumber: jurnal yang diringkas.

\subsection{Kerangka Pemikiran}

Kerangka pemikiran dalam penelitian ini dapat dijelaskan pada gambar berikut ini:

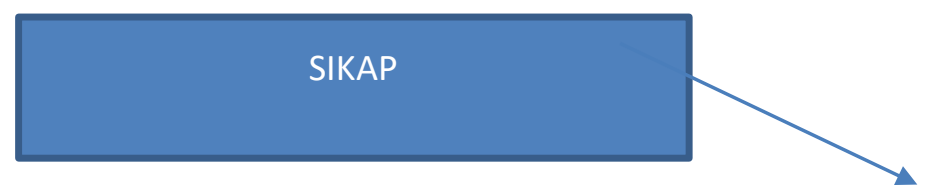

\section{MINAT BERWIRAUSAHA}

\section{PENDIDIKAN}

\section{KKEWIRAUSAHAAN}

Gambar 1. Kerangka Pemikiran

Sumber: Hasil olahan sendiri

Variabel yang diteliti dalam penelitian ini yaitu variabel bebas berupa sikap (X1) dan pendidikan kewirausahaan (X2), dan variabel terikat berupa minat berwirausaha (Y). Dari gambar tersebut menunjukkan bahwa variabel sikap dan pendidikan kewirausahaan berpengaruh terhadap minat berwirausaha. 


\subsection{Pengembangan Hipotesis Penelitian}

Sikap seseorang dapat dilihat dari reaksinya atau responnya atas suatu obyek atau kegiatan. Respon tersebut dapat berupa perasaan suka atau tidak suka. Jika perasaannya suka maka kecenderungannya akan berminat untuk melakukan kegiatan tersebut sedangkan jika perasaannya tidak suka maka tidak akan berminat untuk melakukan kegiatan. Hasil penelitian sebelumnya yang menyatakan bahwa sikap mempunyai pengaruh positif dan signifikan terhadap minat berwirausaha pada mahasiswa pernah dilakukan oleh Ardiyani dan Kusuma (2016), dan Winarsih (2014).

Di dalam pendidikan kewirausahaan terjadi kegiatan mentransfer kompetensi kewirausahaan yang berupa konsep, ketrampilan dan kesadaran mental dalam berwirausaha. Pendidikan kewirausahaan dapat dilakukan secara formal dan non formal. Pendidikan kewirausahaan mempunyai peran dalam membentuk pola pikir dan memotivasi dalam berwirausaha. Salah satu upaya untuk menumbuhkan minat berwirausaha adalah melalui pendidikan kewirausahaan. Hasil penelitian sebelumnya yang menyatakan bahwa pendidikan kewirausahaan mempunyai pengaruh yang positif dan signifikan terhadap minat berwirausaha pada mahasiswa pernah dilakukan oleh Ardiyani dan Kusuma (2016), dan Adhitama (2014).

Dari uraian tersebut maka dapat dimunculkan hipotesis sebagai berikut: 1)Sikap berpengaruh positif dan signifikan terhadap minat berwirausaha pada mahasiswa Program Studi Manajemen, FEB Universitas Wijaya Kusuma Surabaya; dan 2)Pendidikan kewirausahaan berpengaruh positif dan signifikan terhadap minat berwirausaha pada mahasiswa Program Studi Manajemen, FEB Universitas Wijaya Kusuma Surabaya.

\section{METODE PENELITIAN}

Tipe penelitian ini merupakan penelitian eksplanatori yang menjelaskan hubungan antara variabel bebas dengan variabel terikat. Pendekatannya bersifat kuantitatif dimana data dari hasil kuesioner disajikan dalam bentuk angka dan dianalisis secara statistik. Pengumpulan data dilakukan melalui penyebaran kuesioner kepada responden. Populasinya adalah mahasiswa FEB Universitas Wijaya Kusuma Surabaya. Prosedur penentuan sampel menggunakan teknik purposive sampling dengan kriteria: Mahasiswa Program Studi Manajemen Pada FEB Universitas Wijaya Kusuma Surabaya yang Sedang atau sudah menempuh mata kuliah Kewirausahaan. Variabel bebas berupa Sikap dan Pendidikan Kewirausahaan sedangkan Minat berwirausaha sebagai variabel terikat. Pengukuran indikator dengan skala likert (1 sampai 5). Analisisnya dengan regresi linier berganda dan pengujian hipotesis dengan uji t. Definisi operasional sikap adalah ekspresi perasaan , pendapat dan keyakinan responden dalam memandang kegiatan berwirausaha. Definisi operasional pendidikan kewirausahaan adalah materi dan proses pembelajaran mata kuliah Kewirausahaan yang diberikan kepada responden serta sarana prasarana yang digunakan. Definisi operasional minat berwirausaha adalah keinginan responden untuk menjalankan usahanya sendiri.

\section{HASIL DAN PEMBAHASAN}

\subsection{Hasil}

Dari 79 sampel yang memenuhi syarat untuk diolah dengan menggunakan analisis regresi linier berganda diperoleh persamaan regresi sebagai berikut: $Y=11,571+0,635 \mathrm{X} 1+0,214 \mathrm{X} 2$. Dengan demikian variabel sikap (X1) dan pendidikan kewirausahaan (X2) mempunyai pengaruh yang positif terhadap minat berwirausaha. Tabel berikut menunjukkan hasil pengujian hipotesis dengan menggunakan uji t:

Tabel 3. Nilai t_hitung, t_tabel dan signifikansi

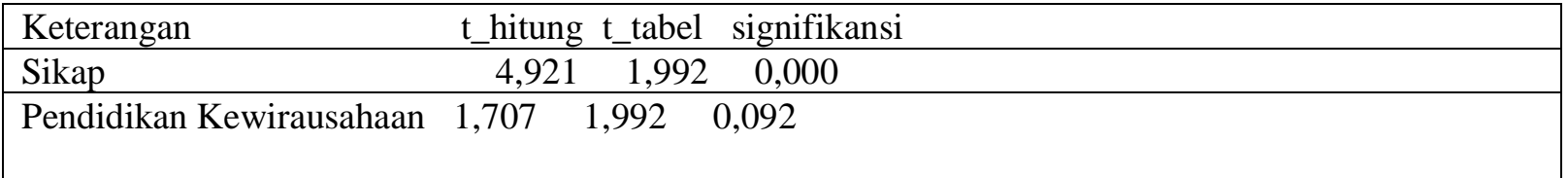


Sumber: Data yang diolah.

Dari tabel 1 dapat dilihat bahwa variabel sikap mempunyai pengaruh yang signifikan dan variabel pendidikan kewirausahaan tidak berpengaruh secara signifikan terhadap minat berwirausaha pada mahasiswa Program Studi Manajemen Fakultas Ekonomi dan Bisnis Universitas Wijaya Kusuma Surabaya. Sikap mempunyai pengaruh yang signifikan terhadap minat berwirausaha karena memiliki nilai t_hitung lebih besar daripada t_tabel yaitu 4,921 lebih besar daripada 1,992 dengan signifikansi sebesar 0,000 yang lebih kecil daripada 0,05. Adapun pendidikan kewirausahaan tidak berpengaruh secara signifikan terhadap minat berwirausaha karena memiliki nilai t_hitung yang lebih kecil daripada t_tabel yaitu 1,707 yang lebih kecil daripada 1,992 dengan signifikansi sebesar 0,092 yang lebih besar daripada 0,05 .

\subsection{Pembahasan}

Sikap berpengaruh positif dan signifikan terhadap minat berwirausaha pada mahasiswa program studi manajemen di Fakultas Ekonomi Dan Bisnis Universitas Wijaya Kusuma Surabaya. Minat berwirausaha di kalangan mahasiswa akan semakin tumbuh apabila penanaman sikap kewirausahaan semakin ditumbuhkan antara lain melalui sikap percaya diri, inisiatif, jiwa kepemimpinan,keberanian dalam mengambil risiko dan kreatif. Yang (2013) berpendapat bahwa seseorang yang bersikap positif terhadap kegiatan kewiraussahaan akan berminat menjadi wirausaha.

Berwirausaha tidak boleh dilakukan dengan ragu-ragu. Oleh sebab itu maka sikap percaya diri perlu terus ditumbuhkan. Semakin percaya diri maka semakin tidak ragu lagi untuk berwirausaha dan berani mengambil risiko karena kegiatan berwirausaha penuh dengan tantangan dan risiko namun demikian terdapat harapan berupa penghasilan yang besar.

Berinisiatif dalam memunculkan ide usaha merupakan langkah awal ketika akan berwirausaha. Banyak cara yang dapat dilakukan dalam memunculkan ide usaha antara lain dengan mengamati lingkungan tertentu, bahan baku yang tersedia di suatu wilayah tertentu, data dari Badan Pusat Statistik (B.P.S) dan keahlian masyarakat di suatu daerah. Ide usaha yang sudah dipilih kemudian diwujudkan dalam bentuk produk yang bernilai. Inisiatif ide usaha yang sudah dimunculkan perlu didukung daya kreatifitas artinya mampu melakukan inovasi yang dapat membedakan usaha yang sudah ada sebelumnya. Untuk itu seorang wirausahawan perlu memiliki ketrampilan dan berwawasan luas.

Dalam berwirausaha diperlukan jiwa kepemimpinan berupa kemampuan dalam mengendalikan, mengelola dan mengalokasikan sumber daya yang dimiliki yang akan digunakan untuk berwirausaha.

Seorang wirausahawan sebagai pemilik usaha memiliki kebebasan dalam bekerja dan kekuasaan dalam membuat keputusan.

Dalam penelitian ini variabel pendidikan kewirausahaan mempunyai pengaruh yang positif namun tidak berpengaruh secara signifikan terhadap minat berwirausaha pada mahasiswa Program Studi Manajemen Fakultas Ekonomi Dan Bisnis Universitas Wijaya Kusuma Surabaya. Artinya mata kuliah Kewirausahaan yang ditempuh mahasiswa bukan menjadi penentu munculnya minat berwirausaha di kalangan mahasiswa. Pihak fakultas dan pengampu mata kuliah Kewirausahaan harus berusaha semaksimal mungkin untuk menjadikan mata kuliah Kewirausahaan sebagai pemicu munculnya minat berwirausaha di kalangan mahasiswa antara lain dengan melakukan penataan kembali materi mata kuliah Kewirausahaan, proses pembelajaran, perbaikan sarana dan prasarana perkuliahan.

Materi perkuliahan sebaiknya dari dosen pengampu dan pelaku usaha dalam bentuk kuliah tamu. Mahasiswa perlu dibekali dengan praktik berwirausaha secara langsung di lapangan sehingga dapat mengetahui hal-hal yang sesungguhnya terjadi ketika berwirausaha antara lain pengetahuan dan pemikiran tentang kewirausahaan, suka duka berwirausaha, menyelesaikan masalah, menghadapi risiko. 
Dengan memiliki pengalaman langsung melakukan kegiatan berwirausaha maka diharapkan dapat memicu tumbuhnya minat berwirausaha bagi mahasiswa. Hal ini sesuai dengan Teori Karir Kognitif Sosial oleh Lent, Brown and Hackett dalam Farzier and Niehm seperti dikutip Adhitama (2014) bahwa pembentukan Minat karir dapat ditumbuhkan melalui pengalaman langsung yang pernah dilakukan seseorang yang berkesan bagi dirinya. Pengalaman secara langsung tersebut dapat dijadikan sebagai latihan dalam menerima umpan balik dan juga untuk mengembangkan ketrampilan yang sudah dimilikinya.

\section{KESIMPULAN DAN SARAN}

Dari hasil penelitian ini dapat disimpulkan sebagai berikut: 1)sikap mempunyai pengaruh yang positif dan signifikan terhadap minat berwirausaha pada mahasiswa Program Studi Manajemen Fakultas Ekonomi Dan Bisnis Universitas Wijaya Kusuma Surabaya; dan 2)pendidikan kewirausahaan pengaruhnya positif namun tidak berpengaruh secara signifikan terhadap minat berwirausaha.

Adapun saran yang diusulkan adalah: 1)sikap mahasiswa mengenai kewirausahaan perlu terus ditumbuhkan agar semakin berminat untuk berwirausaha. Upaya yang bisa dilakukan untuk menumbuhkan sikap kewirausahaan antara lain dengan menanamkan sikap percaya diri, inisiatif, berani mengambil risiko, pantang menyerah dan kreatif; 2)Mahasiswa yang menempuh mata kuliah Kewirausahaan pada akhir semester diwajibkan mengikuti praktik berwirausaha atau pameran produk kreatif Agar jiwa kewirausahaannya semakin tumbuh; 3)Fakultas harus menata kembali proses pembelajaran pendidikan kewirausahaan dalam hal materi, metode dan sarana prasarana. Pendidikan kewirausahaan tidak hanya dilakukan di dalam kelas berupa teori tetapi harus disertai dengan praktik langsung berwirausaha; dan 4)Peneliti selanjutnya diharapkan menambah variabel bebas yang belum diteliti dalam penelitian ini, misalnya lingkungan keluarga, ekspektasi pendapatan dan motivasi.

Keterbatasan penelitian ini terletak pada: 1)variabel bebas yang diteliti, dimana hanya menggunakan dua variabel bebas yaitu sikap dan pendidikan kewirausahaan; dan 2)Yang diteliti hanya mahasiswa program studi manajemen.

\section{DAFTAR PUSTAKA}

(1) Adhitama, Paulus Patria., "Faktor-Faktor Yang Mempengaruhi Minat Berwirausaha: Studi Kasus Mahasiswa Fakultas Ekonomi Dan Bisnis UNDIP," Skripsi, Semarang, Universitas Diponegoro, 2014.

(2) Ardiyani, Ni Putu Pebi Dan Kusuma, A. A. G. Agung Artha., "Pengaruh Sikap, Pendidikan Dan Lingkungan Keluarga Terhadap Minat Berwirausaha," Jurnal Manajemen UNUD, vol.5, no.8, hal.5155-5183, 2016.

(3) Azwar, Budi., "Analisis Faktor-Faktor Yang Mempengaruhi Niat Kewirausahaan (Entrepreneurial Intention): Studi Terhadap Mahasiswa Universitas Islam Negeri Suska Riau," Menara, vol.12, no.1, hal.12-22, 2013.

(4) Budiati, Yuli et. Al., "Minat Mahasiswa Menjadi Wirausaha: (Studi Pada Mahasiswa Fakultas Ekonomi Universitas Semarang),”Jurnal Dinamika Sosbud, vol.14, no.1, hal.89-100, 2012.

(5) Chimucheka, Tendai., "The Impact of Entrepreneurship Education on the Establishment and Survival of Small, Micro and Medium Enterprises (SMME)," Journal Economics, vol.4, no.2, hal.157-168, 2013.

(6) Echdar, Saban., "Manajemen Entrepreneurship-Kiat Sukses Menjadi Wirausaha," Yogyakarta, Andi, 2013, hal.2. 
(7) Nursito, Sarwono dan Nugroho, S.J.A., "Analisis Pengaruh Interaksi Pengetahuan Kewirausahaan dan Efikasi Diri terhadap Intensi Kewirausahaan," Kiat Bisnis, vol.5, no.2, hal.148$158,2013$.

(8) Sharma, Lalit and Madan, Pankaj., "Effect Of Individual Factors On Youth Entrepreneurship: A Study Of Uttarakhand State India," Journal Of Global Entrepreneurship Research, vol.4, no.3, hal.112, 2014.

(9) Winarsih, Puji., "Minat Berwirausaha Ditinjau Dari Motivasi Dan Sikap Kewirausahaan Pada Mahasiswa Program Studi Pendidikan Akuntansi Fakultas Keguruan Dan Ilmu Pendidikan Universitas Muhamadiyah Surakarta," Skripsi, Surakarta, Universitas Muhamadiyah, 2014.

(10) Yang, Jianfeng., "The Theory Of Planned Behavior And Prediction Of Entrepreneurial Intention Among Chinese Undergraduates, ” Scientific Journal Publishers Ltd, vol.41, no.3, hal.367-376, 2013. 